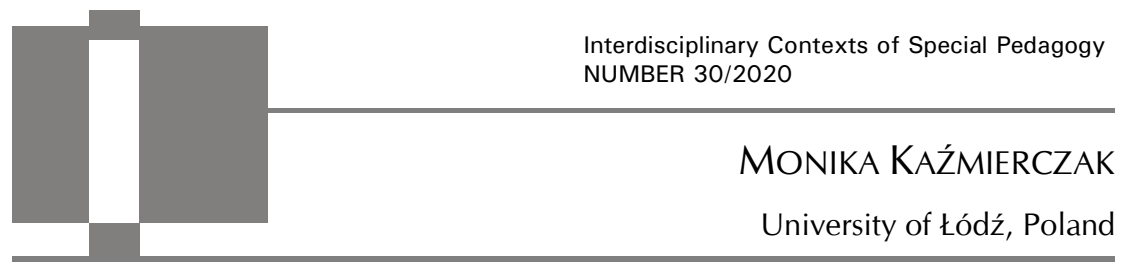

\title{
What is communication? Investigations with kindergarten children
}

\begin{abstract}
Monika Kaźmierczak, What is communication? Investigations with kindergarten children. Interdisciplinary Contexts of Special Pedagogy, no. 30, Poznań 2020. Pp. 88-107. Adam Mickiewicz University Press. ISSN 2300-391X. e-ISSN 2658-283X. DOI: https://doi.org/10.14746/ikps.2020.30.05

Matthew Lipman's P4C (Philosophy for Children) method, which in Poland took the names: philosophising with children, philosophical investigations with children, workshops in philosophy, workshop classes in philosophy, workshops on philosophical research, is based on a discussion in which children are the active participants and creators of the classes. In the course of the investigations, one can observe children's communication behaviour in the dialogue, the level of language and communication skills, the specificity of the child's thinking and the ability to negotiate or interpret meanings in a peer group. The conducted research on communication shows that for five- and six-year-old children 'communication' is primarily about building relationships and reciprocity of linguistic actions.
\end{abstract}

KEY WORDS: communication, dialogue, inquiry, investigation, Philosophy for Children (P4C), kindergarten age children

"[...] it's children, as novices in the world, [...] who believe in the reason for asking questions and looking for answers" 1

${ }^{1}$ E. Martens, Dzieci sa filozofami, filozofowie sa dziećmi, transl. by E. Nowak, „Ethics in Progress Quarterly" 2011, no. 2 p. 4. 


\section{Introduction}

Human development, from the very beginning, is considered from the perspective of controlled changes that lead to "provision of an ever more perfect balance between the individual and their environment, of the perfection of the forms of the adjustment of its relation with the environment" ${ }^{\prime \prime}$, hence, they are progressive. Over the course of developmental changes, a significant mechanism is found in the acquisition of experiences within a specific environment constituting a source of stimuli and information. Within the kindergarten, one can observe both individual as well as social development, in which diverse types of thought processes and linguistic behaviour patterns of the child play an important role. The symbiotic existence of speech and thought, execution and perception activities, is found in the definition of speech offered by Stanisław Grabias. ${ }^{3}$ The researcher indicates that language competences are exercised within situation and grammatical skills, with communication being exercised in course of dialogue and narrative statements ${ }^{4}$. The phrase "transferring $[\ldots]$ its interpretation to others $[\ldots]$ ", included in the definition of speech indicates a necessary condition of communication - language interaction, in course of which thoughts are exchanged and meanings are determined intersubjectively. A preschooler already "begins to differentiate their convictions about reality from reality itself, and from then on, they differentiate their own and others' convictions about that same fragment of reality". ${ }^{5}$

2 M. Przetacznik-Gierowska, G. Makiełło-Jarża, Psychologia rozwojowa i wychowawcza wieku dziecięcego, Wydawnictwa Szkolne i Pedagogiczne, Warszawa 1985, p. 23.

3 "A set of activities performed by man using language, getting to know reality and transferring its interpretation to other participants of social life", Logopedia. Teoria zaburzeń mowy, ed. by S. Grabias, M. Kurkowski, Wydawnictwo Uniwersytetu Marii Curie-Skłodowskiej, Lublin, p. 16.

4S. Grabias, Jezyk w zachowaniach społecznych. Podstawy socjolingwistyki i logopedii, Wydawnictwo Uniwersytetu Marii Curie-Skłodowskiej, Lublin 2019.

5 J. Trempała, Wczesne kompetencje poznawcze w rozwoju dziecka, „WarmińskoMazurski Kwartalnik Naukowy, Nauki Społeczne" 2012, no. 2, p. 13. 
Janusz Trempała indicates that this breakthrough takes place around the fourth year of age.

Thanks to the the common tool of the word, intersubjective rooting of meanings and sense is constantly interpreted or negotiated using spoken language that is aimed at co-creation, "understood as confirmation of certain portions of meanings, as if they were to be constantly updated so as to neutralise retention (the inevitable past) and move to protention - the future as design of the common understanding" ${ }^{6}$ The holistic attitude of the sender and recipient indicated by Jacek Warchala is based on the assumption of active participation in the act of language communication, facilitating the solidification of identity and the establishment of each actual subject. In tasks not exceeding the operational capacities of cognitive processing and participation in dialogue ("dialogue": dia - through, logos - rational word, speech, mind, sense, order, hence dialogue means 'through rational word'), even with limited metalinguistic knowledge and semantic skills of preschoolers, their level of language and communication competences and skills, the specifics of their thinking and openness to intersubjective determination of meanings can be analysed. In contrast to questioning every one [child] separately, dialogue prevents the child from being closed within just their own thought. ${ }^{7}$ Linguistic action in community, in an area that is interesting and democratically selected for discussion by a group of preschoolers, also teaches the adult - among others, to suspend their own knowledge, follow the children, to authentically participate in interpretation of reality and transfer of the relevant results to others. Such an attitude allows one to open up to the children's understanding of communication, and to better understand the mode of communication itself.

${ }^{6}$ J. Warchala, Kategoria potoczności w języku, Wyd. Uniwersytetu Śląskiego, Katowice 2003, p. 266.

${ }^{7}$ According to B. Maryniak, this can be compared to the ancient labyrinth of king Minos, missing here and now some "general frescos" using which the Minotaur could alone learn the rules of induction and deduction to be led out from the corridor mazes "to the stairs of abstraction", B. Maryniak, Logos i paideia, "Logopaedica Lodziensia" 2017, no. 1, pp. 63-77. 


\section{From philosophy for children to philosophy with children}

Professor Matthew Lipman of the Institute for Advancement of Philosophy for Children (IAPC) at Montclair State University in the United States had between the 1960s and 1970s formulated the education curriculum known as Philosophy for Children (P4C). It served the popularisation of the idea of introducing philosophy in the initial stages of school education.

The original assumptions of philosophy for children show a certain kind of paternalism: Children tend to philosophise, their innate curiosity and spontaneous questions, as well as surprising observations, show signs of philosophising, allowing these activities to be considered prephilosophy ${ }^{8}$, or a different kind of philosophy than the one practiced by adults. The children's introduction to true, mature philosophy of adults (philosophy in the proper sense of the word, as practised by cultivated philosophers $\left.{ }^{9}\right)$, requires the development of separate education methods and materials ${ }^{10}$, which, together with suitable teacher competences, would allow the children to learn "true philosophy". In the view of adults, they offer the children the opportunity to learn, which they never had before. Thanks to the curriculum developed specifically for children, the content (only selected - thoughts of key philosophers) are provided in a simpler form. ${ }^{11}$ The preposition for in the original scheme name,

${ }^{8}$ A. Łagodzka, Dyskusja dialogiczna - filozofia dzieciństwa i filozofia dorostych, "Analiza i Egzystencja” 2014, no. 25, pp. 99-123.

${ }^{9}$ G.B. Matthews suggested for philosophy of childhood to be treated analogously to other subareas, such as philosophy of religion, science, art or other subjects included in academic teaching curricula, G. Matthews, The Philosophy of Childhood. Harvard University Press, Cambridge MA 1994.

10 Philosophy for children encompasses all educational suggestions developed with non-adults in mind. They cover both erudite knowledge of philosophy, as well as philosophical investigations.

11 In Poland, suggestions for the programme were included in many publications meant for children, e.g. S. Boizard, Filozofowie do dzieci, transl. by T. Skowroński, Wydawnictwo Muchomor, Warszawa 2011; M. Fabjański, Wędrówki filozoficzne, Wydawnictwo Wilga, Warszawa 2003; M. Bacchini, E. Di Marco, Zemsta 
being a necessary construct as a counter-reservation would, according to M. Lipman, be required until philosophy without this preposition would be identified with philosophy of adults.

The popularity that the P4C quickly gained, influenced the critical view of the didactic undertaking and a change of the name itself: from philosophy to philosophising and the replacement of the preposition for with with: philosophising with children. This semantic shift shows the difference between the product (something encountered, communicated; erudite knowledge of) and the activities themselves (production through communication), indicates the shift from the expression of erudite knowledge about phenomena as well as reflective and critical consideration ${ }^{12}$ of phenomena and recalled knowledge - to the skill of verification or production of meanings in an act of negotiation/ interpretation during a discussion as a repeated communication and personal experience: "in a thinking group, children think like a »single head «. The individual statements inspire other dialogue participants to formulate their own thoughts, pose further questions, mutual argumentation verifies both the finality and the logic of expressions". ${ }^{13}$ In a group, children gain the possibility of seeing a multitude of interpretations, of forming their own opinions or changing their attitudes, they also attempt to find the best thought-out, substantiated and comprehensive response to a selected issue. This requires both efficient argumentation, the presentation of suitable and convincing examples as well as the skill to aptly yet critically listen to others. ${ }^{14}$

A change of thinking about the undertaken linguistic activities makes thinking itself gain the proper quality during attempts at

Ateny, Platon w krainie paradoksów, Uczta Platona, Wspaniała kraina Atlantydy, WAM, Kraków 2008.

12 For the thinking subject, the consideration or pondering is a mental activity that by its nature does not need the communication of results to others (cerebration in the acommunicative aspect).

13 P. Walczak, Dziecko i filozofia. Spór o filozofowanie dzieci „Analiza i Egzystencja” 2017, no. 38, pp. 16-17.

14 A. Pobojewska, Edukacja do samodzielności Warsztaty z dociekań filozoficznych. Teoria i metodyka, Wydawnictwo UŁ, Łódź 2019. 
common understanding of issues, phenomena, attitudes or texts already existing. At the same time, the creative power of the thinking-speaking-communicating subject (verbalising thoughts in a group, in the open) is stressed, meaning, the shift from a re-creative act to creative independence. ${ }^{15}$ This lack of knowledge and experience is considered a strength, as it allows an unbiased view of things. ${ }^{16}$ Children are open to new experiences, capable of reflection untainted by tendencies, and their outside-the-box thinking and spontaneity means that they are called "natural philosophers". ${ }^{17}$ Gareth B. Matthews, seeking the relations between childhood and philosophy, concluded about the almost natural need of philosophising in children, in particular aged between three and seven years. ${ }^{18}$ Such an approach constitutes the children's right to deal with philosophy, including full participation in dialogue ${ }^{19}$ and philosophical investigations.

15 As A. Pobojewska, one of the supporters of the Lipman programme in Poland, stressed, "philosophy classes do not have erudite objectives (with this task being left to other classes), but try to elicit specific skills, attitudes and motivations. The main competence to be shaped here in the participants, is intellectual and moral sovereignty", A. Pobojewska, Zajęcia warsztatowe z filozofii a relatywizm. Dyrektywa wycofania sie prowadzacego z merytorycznej warstwy dialogu, "Przegląd Filozoficzny Nowa Seria" 2012, no. 3, p. 351.

16 P. Walczak, Dziecko i filozofia. Spór o filozofowanie dzieci "Analiza i Egzystencja” 2017, no. 38, pp. 5-19.

17 Conf. G. Matthews, The Philosophy of Childhood. Harvard University Press, Cambridge MA 1994; G. Matthews, The child as natural philosopher, [in:] Growing up with philosophy, ed. by M. Lipman, A.M. Sharp, Temple University Press, Philadelphia 1978, pp. 63-77; K. Murris, Are children natural philosophers? "Teaching Thinking" 2001, no. 9, pp. 46-49; K. Murris, Can Children Do Philosophy?, "Journal of Philosophy of Education" 2000, no. 34(2), pp. 261-279.

18 In older children, philosophising is less frequent or less revealed. Adult expectations, particularly strong in education space, focus child behaviour on growing up, or development, the objective of which is maturity (subsequent development stages give way to stages of higher maturity). Each earlier activity should in the end serve adulthood, and gains significance primarily in this perspective. A person is most commonly understood as and associated with an adult.

${ }^{19}$ In dialogue (the Socratic method), a question put to a child by an adult is subjected to internal reflection, the effect of which is a statement or response (cerebra- 
Investigation is a term related to the area of linguistic communication, with the presence of others, meaning, direct participants of the didactic-communication situation, in which the communicating subject considers the questions submitted and formulated by themselves or by peers, not just submitting to thinking on statements or questions suggested by adults. A characteristic property of investigation are thought-linguistic activities in a group and simultaneous statements together with the relevant author, putting participants in such situations that every one could ponder their thoughts among others, to confront the effects of thinking and - perhaps - verify or solidify one's views. The meaning of terms and statements is thus established through intellectual dialogue ${ }^{20}$, in which the truth can be conveyed by language - an intersubjective tool.

During investigations with children, the adult plays the role of activity organiser and moderator. One of the guidelines for the teacher or host "is the [methodical] recommendation not to take a position on the material issues considered during the class" ${ }^{21}$

tion in the quasi-communicative aspect), subsequently verbalised. The adult poses questions used to follow the child's train of thought, and gains knowledge from them, instead of running in front of this thought, believing what it might mean. In the prototypical dialogue, the adult moderates the situation, asking (Why?, What for?, What is...?, What are its properties?), leading the child to a solution by posing questions.

${ }^{20}$ More broadly on intellectual dialogue see e.g.: A. Pobojewska, Edukacja do samodzielności Warsztaty z dociekań filozoficznych. Teoria i metodyka, Wyd. UŁ, Łódź 2019; A. Pobojewska, Warsztaty z dociekań filozoficznych - narzędzie edukacji filozoficznej (i nie tylko), [in:] Filozofia - edukacja interaktywna. Metody - środki-scenariusze, ed. by A. Pobojewska, Stentor, Warszawa 2012, pp. 171-216; A. Pobojewska, O dialogu (w kontekście edukacji), [in:] Od twórczości do podmiotowości, ed. by M.K. Stasiak, L. Frydzyńska-Świątczak, Wydawnictwo WSHE, Łódź 2005, pp. 36-48.

21 A. Pobojewska, Zajęcia warsztatowe z filozofii a relatywizm. Dyrektywa wycofania sie prowadzacego z merytorycznej warstwy dialogu, "Przegląd Filozoficzny - Nowa Seria" 2012, no. 3, p. 351. Critique of withdrawal of the host was developed by e.g.: Z. Zdunowski, Edukacja filozoficzna wobec wyzwania relatywizmu na przykładzie programu Matthew Lipmana "Filozofia w szkole”, "Analiza i Egzystencja” 2009, no. 10, pp. 173-185; J. Zubelewicz, Lipmana filozofia dla dzieci - analiza krytyczna, „Kwartalnik Pedagogiczny" 2001, no. 2(180), pp. 67-100. 
With the adult withdrawing from the material layer of the investigation, the intellectual and moral independence of the children has a chance to develop. In the core part of the workshop, verbal activity of the adult boils down mainly to posing supporting questions (Why do you think so? How is this related to...? What do you mean when you say...? Can you give an example? etc.), simplifying the formulation of arguments, making differentiations, giving substantiations, interpreting own and others' statements, specifying term meanings, undertaking diverse other thought-verbal activities facilitating the course of the investigation. As the organiser, the adult is obliged to respect the workshop structure, made up of five components:

1. Seating the participants in a circle.

2. Loud reading of a text or watching a visual material, or performing an exercise.

3. Formulation of questions by users.

4. Selection of questions for discussion.

5. Discussion.

\section{What does it mean "to communicate"? Investigations with five- and six-year-olds}

Investigations with five- and six-year-olds, the objective of which is to determine, what is communication according to children, were conducted at a kindergarten in Łódź, Poland. Four groups took part in the workshops: two groups of five-year-olds (I and II, both five-person) and two groups of six-year-olds (III, with six persons, and IV, with eight persons). Cognitive development of all of the preschoolers was normative, the speech impediments diagnosed by the kindergarten speech therapist did not influence the quality of participation in the meetings. None of the children had ever participated in such workshops.

At the beginning of the workshop, an image was placed presenting a boy or a girl (fig. 1) before each group that sat in a circle (the children were free to choose their specific place) - each group had 
only one of the two images chosen for them at random. It was drawn by hand and schematically so that it would not draw too much attention during the meeting.

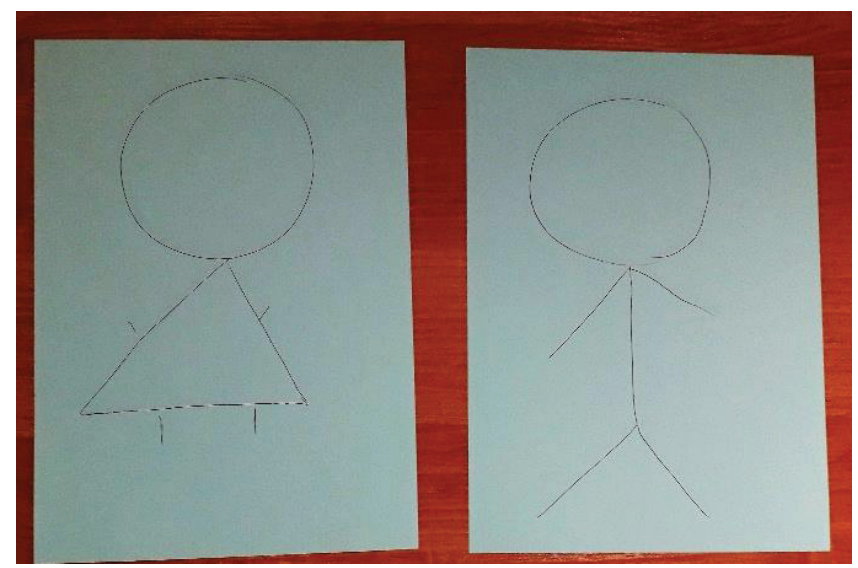

Fig. 1. Boy and girl images used during investigations with preschoolers Source: private archive

Above the image, a colour inscription "I SPEAK" was placed, with a small question mark lying in front of each child on a smaller piece of paper (fig. 2). Before commencement of the workshop proper, the host read the inscription to the children and explained the significance of the question mark.

At the beginning of class, the leader set out rules bringing the workshop course to order. The children indicated:

1. Speaking one after another

2. Raising one's hand before speaking

3. Listening to statements by others until the end, without interrupting.

The host suggested in addition:

4. Respecting the ideas of others (not ridiculing others),

5. Remaining at the same spot during the class. 


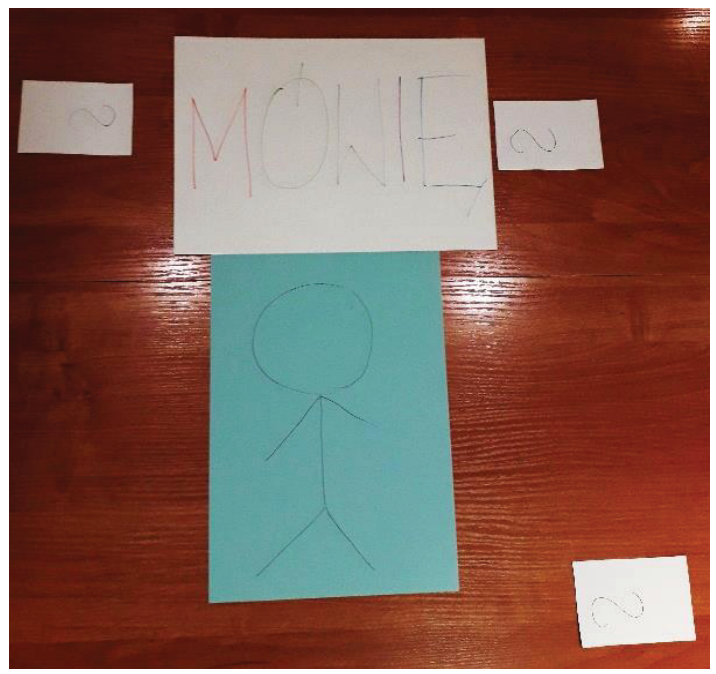

Fig. 2. Distribution of the aids prepared for each workshop group Source: private archive

The acceptance of a uniform set of rules during class brings the organisation to order, preventing the disintegration of the text spoken by a participant, e.g. intervening in the message to be transmitted even during its formulation (ad hoc corrections of noticed errors, inconsistencies, expressing different opinions during statements by others, etc.).

For the workshop proper, each group was given the same task: What question comes to your mind when you look at the sheets? or What would you like to ask when you look at the sheets?22 Among the groups, three, I, III and IV, considered all prepared aids, however only two, I and IV ${ }^{23}$ focused on communication - the effects of the investigations will be presented in the latter part of the study.

22 The question form was modified depending on the group, so that children understood the command.

${ }^{23}$ In group III, the children selected the question: Who is the girl?, even though questions included those related to linguistic communication. In group II, the ques- 
Following careful observation of the aids and a short period of thinking, the children from both groups formulated the following questions ${ }^{24}$ :

What does it mean, is the figure speaking?

Is the figure walking along the street?

Is somebody speaking to them?

Is somebody speaking to them and [they] are answering?

Are they going... to preschool/ to school to the station/ home/ to the store/ to work?

Are they on the phone?

Are they praying?

Are they going to confess and praying?

Is the word in their head?

Are they going to pee?

Who is he/ she?

Is he a boy?

The host would write down ${ }^{25}$ the questions on a sheet of paper, and after the "brainstorm" ended, read them out again and held a vote. In course of the workshop, two groups: one of five- and one of six-year-olds, selected from among the questions posed by their peers the same one with a majority vote: Is somebody speaking to them and [they] are answering? Hence, the children decided to consider, what does it mean "to communicate".

During the discussion, the young participants attempted to explain their understanding of the term very precisely, and to support the arguments, they gave numerous examples from own communication experience. The examples applied mainly to behaviour ob-

tions circled around "the person's trip" (purpose, reasons, preparations, companions, etc.), when formulating questions the children generally failed to consider the 'I speak' sheet.

24 The forms of questions with the same content and sounding similarly were unified for the paper.

${ }^{25}$ During investigations with older participants, one of the workshop participants becomes a secretary, howver, preschoolers should be relieved of this task. 
served at the kindergarten, but also home and in the immediate environment. According to preschoolers, the definition of "communication" includes such components as:

1. Relations between interlocutors: e.g. be the same, similar; one can play with someone; play ball; when someone hits you, they say they're sorry; don't argue; make friends; get married. Statements concerning relations and attitudes as well as relevant examples, also characterising adult lives, were most numerous during discussions in both groups.

2. Mutual linguistic activity of at least two participants in a communication event: e.g. speak/ talk with someone; talk with a friend; and what if they don't respond...? THe children clearly stressed differences between the transitive form (unilateral conveyance of a message) and interaction (message exchange, linguistic behaviour observed in the social process), in which direct influence of someone on another occurs.

3. Diversity of forms making up the message: e.g. expressing my voice; talking with hands [gestures]; you have to greet the other person; "high five". Due to limited metalinguistic awareness, preschoolers were unable to precisely name the various kinds of communication channels, however, they did notice the coexistence of many levels, on which communication takes place, among them: verbal, phonic, kinesic, proxemic, behavioural, etc.

4. Conditions of effective linguistic communication: e.g. you understand what someone is saying; come to terms; that you can hear them; you have to listen; you have to speak; you have to use your ears and head. The children enumerated components related to the initiation of verbal contact, the comprehension of the intent of the sender or the rules of linguistic etiquette.

The last discussion area (conditions of effective communication) became in both groups the invitation to a participant-initiated ${ }^{26}$ in-

26 The open crayon box lying on the table turned out to be an unspoken encouragement for the children to draw on the other sides of the question mark sheets. The 
tersemiotic translation. The children expressed the need to graphically represent body parts necessary to communicate, with each group completing the undertaken task in a different manner.

In group I, each child drew a figure ${ }^{27}$ on their sheet, with components necessary for communication (fig. 3), with group IV amending the girl image with parts of her body that are important for the communication process yet not included or not sufficiently stressed on her schematic drawing (fig. 4):

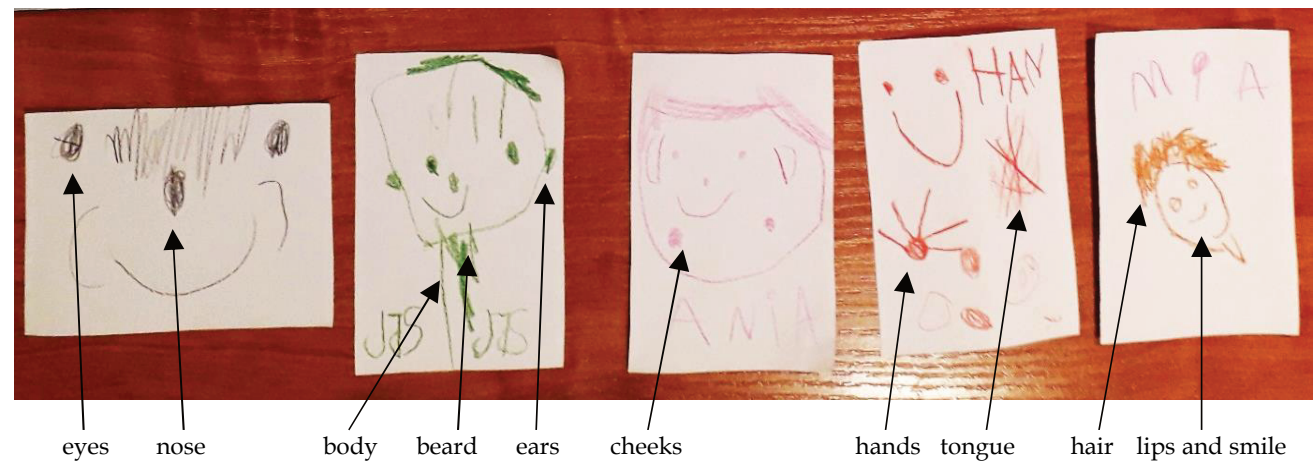

Fig. 3. Body parts necessary for communication - according to group I Source: private archive.

When the drawing was completed, the host asked the children to explain why the components they recreated are important for communication, and in what way do they condition it. Apart from the most obvious components of systems and organs utilised while speaking and comprehending (eyes: you have to see, who you are talking to; whether they did not go away; whether they see that I am talking to them;

consent of the host to the first and subsequent questions of the children: Auntie, can I draw... and following the children at this stage amended the workshop with an unplanned component.

${ }^{27}$ The term from the original Polish language version of the paper, 'ludzik', is a general one meaning roughly 'small person' [translator's note] 


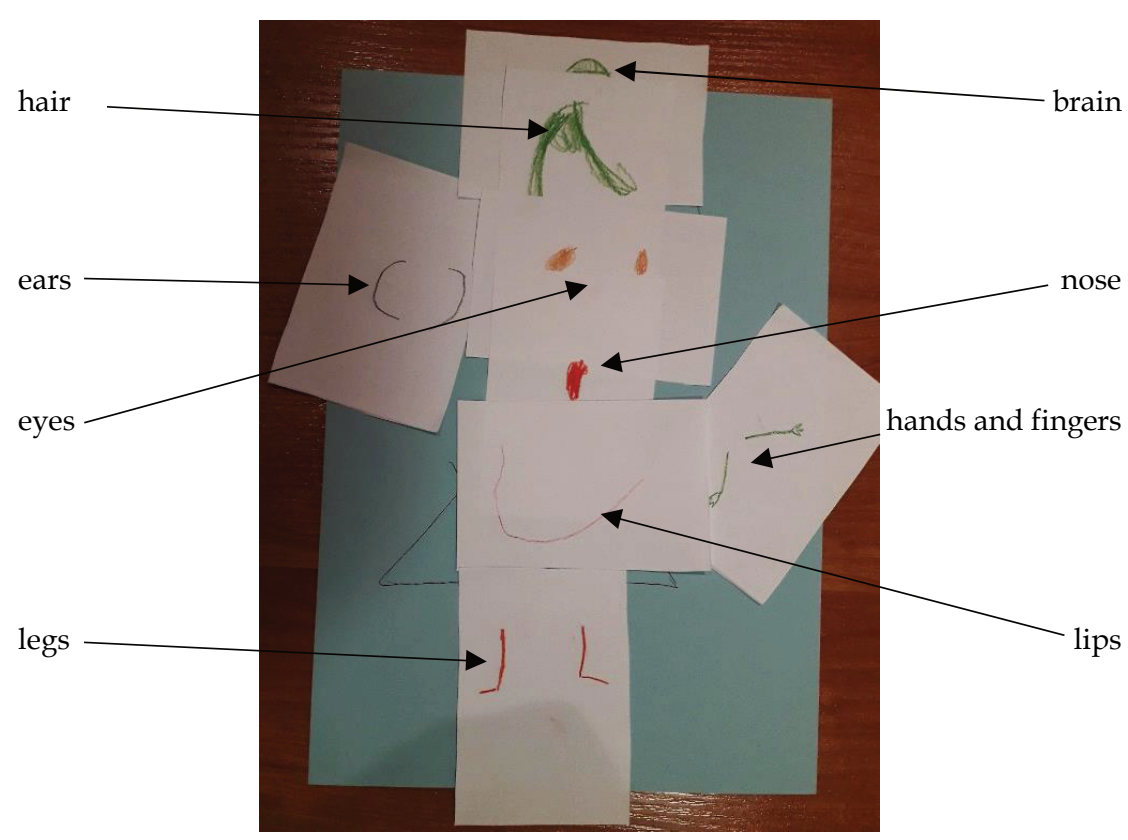

ears: that you can hear something; you need to listen; you need to use your ears and head; lips and smile: you talk with your mouth; when I smile, I say that I like someone, tongue: I once bit it when training football, it hurt, and I did not talk); one of the six-year-olds drew a brain, explaining: you have to think about what to say and what the other person is saying. Children in both groups explained that the beards and cheeks move, hence you can see that somebody is talking. Moreover, the cheeks turn red when somebody is nervous, but they have to say they're sorry for bad behaviour (when somebody hits [you]...), hence, the legs talk (nervour stomping on the ground, a heavy gait, feet shuffling or stomping because of discontent). The nose can say the smell is bad, and the hair that I have a nice hairpin. Hands and fingers show what one is saying (talking with hands) or execute the will to greet another ("high five"). In general, the entire body talks to the other person - one of the five-year-olds summarised the workshop at the end. 


\section{Discussion and conclusions}

The conducted research shows that the Polish version of the M. Lipman method may be successfully used to define (define - 'explain meaning; definition ${ }^{28}$ - "explaining word, phrase or term meanings", Dictionary of the Polish Language) terms already with preschoolers who know terms from preerudite experience. The presented research results, like other projects executed in Poland using philosophical investigations ${ }^{29}$ confirm that this method provides the children with the possibility to convey their individual understanding of reality and to interpret or negotiate meanings in dialogue.

Such intersubjective negotiation of terms requires a holistic approach to verbal communication, including attention focus on each participant in spoken dialogue (speaker-listener, listener), the relation between them, the situation and the context, in which the statement is interpreted (speech act or a sequence thereof), based on spoken word. During the workshops, the children eagerly posed questions, formulating them suitably to the presented materials, expanded upon and amended peer ideas. They had exhibited readiness to handle a question posed by another, were keen to make the joint effort to consider an issue, with talking itself giving them pleasure. A certain impatience and distraction became noticeable towards the end of the class, when the children considered the topic to have been exhausted.

Joint investigations significantly reduced the fear of speaking out or responding. ${ }^{30}$ preschoolers entered the dialogue on the basis

${ }^{28}$ Linguistics differentiate between defintion and explication. When explicating, the sender moves from word to object, when defining - vice versa, from the object to the word, B. Boniecka, Definicje i eksplikacje dziecięce, [in:]: Zaburzenia mowy. Mowa. Teoria. Praktyka, ed. by S. Grabias, Wydawnictwo Uniwersytetu Marii Curie-Skłodowskiej, Lublin 2001, pp. 159-174.

${ }^{29}$ Conf. Wąsik B., Dziecko filozofem. O projekcie edukacyjnym FiloZosia - filozofia dla przedszkolaków, „ARGUMENT: Biannual Philosophical Journal” 2018, no. 8(1), pp. 87-204.

30 Fear of errors, lack of knowledge or speaking in groups may be noticed during discussions with preschool groups or in individual contacts with children (e.g. during diagnosis). 
of sovereign decisions (during the class, each preschooler spoke at least three times), they were able to effectively participate in the discussion, respected its fundamental rules and terms of participation set out at the beginning of the class. Thanks to adherence to orderliness, the children focused on the task and encouraged themselves mutually to perform linguistic tasks - submitted their own ideas, referred to peer opinions and compared attitudes (Me too..., And I in turn...), amended and explained own observations (...I wanted to add that...), gave numerous examples, defended their positions, respecting others' opinions. The rules of statement authenticity ${ }^{31}$ applied by the children gave rise to the presence of true intellectual dialogue.

In their statements, the preschoolers frequently formulated conclusions in line with the relevant discipline. The studied groups showed components referring closely to the dictionary definition of communication, meaning, concerning "making contact with someone", or communicating with another primarily by words, and "coming to an understanding on a certain issue" (Dictionary of the Polish Language). Attempts at explication were apt, even though in actual dialogue the children would frequently amend peer statements, hence, failing to consider all formal-linguistic definition components. Preschoolers noted many properties and conditions of communication that were not included in the dictionary definition (e.g. layer diversity, conditions of effective communication).

The semantic skills of preschoolers, or the ability to differentiate between information emerging along the line: language - thinking reality 32 , may surprise an adult able to get to know the train of thought of children and the world view embedded in preschooler

31 The rule of statement authenticity is "voluntary statement of opinions, about which [participants] themselves are convinced", A. Pobojewska, Zajęcia warsztatowe $z$ filozofii a relatywizm. Dyrektywa wycofania sie prowadzacego z merytorycznej warstwy dialogu, „Przegląd Filozoficzny - Nowa Seria” 2012, no. 3, p. 353.

32 H. Borowiec, Sprawność semantyczna dzieci w wieku przedszkolnym, [in:] Zaburzenia mowy. Mowa. Teoria. Praktyka, ed. by S. Grabias, Wydawnictwo Uniwersytetu Marii Curie-Skłodowskiej, Lublin 2001, pp. 151-157. 
language during the investigation. In course of the initiated dialogue, it turned out that for preschoolers communication is mainly building relations, and "Personal relation excludes reification of a human being, domination or subordination of any of the parties to the dialogue". 33 The need to be within a communicating community is expressed by the children through mutual linguistic activities ${ }^{34}$, which are more to them than just transmission of data, verbal conveyance or enforcement of memorised content. As Aldona Pobojewska notes, investigation workshops "may be used on all education levels, from preschool to university of the third age, in all types of schools and education facilities, as well as at other education institutions (youth detection centres, culture centres, language schools, during projects, etc.)"35, as they serve the preliminary consideration of diverse types of issues related to the topic at hand and the world around us.

\section{References}

Bacchini M., Di Marco E., Zemsta Ateny, Platon w krainie paradoksów, Uczta Platona, Wspaniała kraina Atlantydy, WAM, Kraków 2008.

Boizard S., Filozofowie do dzieci, transl. by T. Skowroński, Wydawnictwo Muchomor, Warszawa 2011.

Boniecka B., Definicje i eksplikacje dziecięce, [in:] Zaburzenia mowy. Mowa. Teoria. Praktyka, ed. by Grabias S., Wydawnictwo Uniwersytetu Marii Curie-Skłodowskiej, Lublin 2001, pp. 159-174.

${ }^{33}$ M. Kaźmierczak, Binary and Ternary Relation between Participants ofthe Diagnostic and Therapeutic Process in Speech-language Pathology. Interdisciplinary Contexts of Special Pedagogy, No. 20, Poznań 2018. p. 156.

34 B. Dobek-Ostrowska mentions over one hundred definitions of communicating and communication, developed by researchers in diverse fields. Even though they note various aspects (message and information exchange, usage of verbal and non-verbal resources, transactionality, creation of meaning, construction of social relations, exercising control), they agree that communication is a process, hence, an activity, B. Dobek-Ostrowska Komunikowanie polityczne i publiczne, Wyd. Nauk. PWN, Warszawa 2006.

35 A. Pobojewska, Edukacja do samodzielności. Warsztaty z dociekań filozoficznych. Teoria i metodyka, Wyd. UŁ, Łódź 2019, p. 17. 
Borowiec H., Sprawność semantyczna dzieci w wieku przedszkolnym, [in:] Zaburzenia mowy. Mowa. Teoria. Praktyka, ed. by Grabias S., Wydawnictwo Uniwersytetu Marii Curie-Skłodowskiej, Lublin 2001, pp. 151-157.

Dobek-Ostrowska B., Komunikowanie polityczne i publiczne, Wyd. Nauk. PWN, Warszawa 2006.

Fabjański M., Wędrówki filozoficzne, Wydawnictwo Wilga, Warszawa 2003.

Grabias S., Jezzyk w zachowaniach społecznych. Podstawy socjolingwistyki i logopedii, Wydawnictwo Uniwersytetu Marii Curie-Skłodowskiej, Lublin 2019.

Kaźmierczak M., Binary and Ternary Relation between Participants ofthe Diagnostic and Therapeutic Process in Speech-language Pathology. Interdisciplinary Contexts of Special Pedagogy, No. 20, Poznań 2018. p. 156.

Logopedia. Teoria zaburzeń mowy, ed. by S. Grabias, M. Kurkowski, Wydawnictwo Uniwersytetu Marii Curie-Skłodowskiej, Lublin 2014.

Łagodzka A., Dyskusja dialogiczna - filozofia dzieciństwa i filozofia dorostych, "Analiza i Egzystencja" 2014, no. 25, pp. 99-123.

Matthews G., The Philosophy of Childhood, Harvard University Press, Cambridge MA 1994.

Matthews G., The child as natural philosopher, [in:] Growing up with philosophy, ed. by M. Lipman, A.M. Sharp, Temple University Press, Philadelphia 1978, pp. 63-77.

Maryniak B., Logos i paideia, „Logopaedica Lodziensia” 2017, no. 1, pp. 63-77.

Murris K., Can Children Do Philosophy?, "Journal of Philosophy of Education" 2000, no. 34(2), pp. 261-279.

Murris K., Are children natural philosophers?, “Teaching Thinking” 2001, no. 9, pp. 46-49.

Pobojewska A, Edukacja do samodzielności. Warsztaty z dociekań filozoficznych. Teoria i metodyka, Wyd. UŁ, Łódź 2019.

Pobojewska A, Zajęcia warsztatowe $z$ filozofii a relatywizm. Dyrektywa wycofania się prowadzacego z merytorycznej warstwy dialogu, „Przegląd Filozoficzny - Nowa Seria" 2012, no. 3, pp. 351-363.

Pobojewska A., Warsztaty z dociekań filozoficznych - narzędzie edukacji filozoficznej (i nie tylko), [in:] Filozofia - edukacja interaktywna. Metody - środki - scenariusze, ed. by A. Pobojewska, Stentor, Warszawa 2012, pp. 171-216.

Pobojewska A., O dialogu (w kontekście edukacji), [in:] Od twórczości do podmiotowości, M.K. Stasiak, L. Frydzyńska-Świątczak, Wydawnictwo WSHE, Łódź 2005, pp. 36-48.

Przetacznik-Gierowska M., Makiełło-Jarża G., Psychologia rozwojowa $i$ wychowawcza wieku dziecięcego, Wydawnictwa Szkolne i Pedagogiczne, Warszawa 1985.

Trempała J., Wczesne kompetencje poznawcze w rozwoju dziecka, „Warmińsko-Mazurski Kwartalnik Naukowy, Nauki Społeczne” 2012, no. 2, pp. 9-22.

Walczak P., Dziecko i filozofia. Spór o filozofowanie dzieci „Analiza i Egzystencja” 2017, no. 38, pp. 5-19.

Warchala J., Kategoria potoczności w języku, Wyd. Uniwersytetu Śląskiego, Katowice 2003. 
Wąsik B., Dziecko filozofem. O projekcie edukacyjnym FiloZosia - filozofia dla przedszkolaków, „ARGUMENT: Biannual Philosophical Journal” 2018, no. 8 (1), pp. 87-204.

Zdunowski Z. Edukacja filozoficzna wobec wyzwania relatywizmu na przykładzie programu Matthew Lipmana "Filozofia w szkole”, "Analiza i Egzystencja” 2009, no. 10, pp. 173-185.

Zubelewicz J., Lipmana filozofia dla dzieci - analiza krytyczna, „Kwartalnik Pedagogiczny" 2001, no. 2 (180), pp. 67-100.

\section{On-line literature}

Martens E., Dzieci sa filozofami, filozofowie sa dziećmi, transl. by E. Nowak, "Ethics in Progress Quarterly" 2011, no. 2, www.ethicsinprogress.org, access: 15.02.2020.

Stownik jezyka polskiego, PWN, https:/ / sjp.pwn.pl/, access: 28.02.2020.

List of abbreviations

SJP - Dictionary of the Polish Language 